\title{
Microencapsulation of essential thyme oil by spray drying and its antimicrobial evaluation against Vibrio alginolyticus and Vibrio parahaemolyticus
}

\author{
O. Tomazelli Júnior ${ }^{a}$, F. Kuhn ${ }^{b}$, P. J. M. Padilhac, L. R. M. Vicente, \\ S. W. Costa ${ }^{c}$, A. A. Boligon , J. Scapinello ${ }^{b}$, C. N. Nesi ${ }^{c}$, J. Dal Magro ${ }^{b}$ and S. Lamo Castellvia* \\ aDepartament d'Enginyeria Química, Universitat Rovira i Virgilli - URV, Av. Països Catalans, 26, 43007, Tarragona, Spain \\ bPrograma de Pós-graduação em Ciências Ambientais, Universidade Comunitária da Região de Chapecó - \\ UNOCHAPECÓ, Av. Atílio Fontana, 591, CEP 89809-000, Chapecó, SC, Brazil \\ ${ }^{\circ}$ Centro de Desenvolvimento da Aquicutura e Pesca - CEDAP, Av. Admar Gonzaga, 1188, Itacorubi, CEP 88010-970, \\ Florianópolis, SC, Brazil \\ ${ }^{d}$ Laboratório de Fitoquímica, Departamento de Farmácia Industrial, Universidade Federal de Santa Maria - UFSM, \\ Av. Roraima, 1000, Prédio 26, Sala 1115, Camobi, CEP 97105-900, Santa Maria, RS, Brazil \\ *e-mail: silvia.delamo@urv.cat
}

Received: June 20,2016 - Accepted: October 25, 2016 - Distributed: May 31, 2018

(With 2 figures)

\begin{abstract}
The aims of this research were first, to evaluate the antibacterial potential of commercial thyme essential oil against $V$. alginolyticus and $V$. parahaemolyticys and second, using the spray drying technique to produce microcapsules. chemical compounds of thyme oil and microcapsules were identified and quantified being thymol the chemical component present at the highest concentration. Oil-in-water $(\mathrm{O} / \mathrm{W})$ emulsions were prepared and the microcapsules were obtained with a spray dryer using maltodextrin as wall material (ratio 1:4). Thyme oil and the microcapsules exhibited antimicrobial activity against $V$. parahaemolyticus and $V$. alginolyticus. The spray drying process did not affect the antimicrobial activity of thyme essentialoil.
\end{abstract}

Keywords: essential oil, Thymus vulgaris, Thymus zygis, bacterial control, aquaculture.

\section{Microencapsulação do óleo essencial de tomilho e avaliação de sua atividade antibacteriana sobre $V$. alginolyticus e $V$. parhaemolyticus}

\begin{abstract}
Resumo
Os objetivos desta pesquisa foram avaliar o potencial antibacteriano do óleoessencial de tomilho sobre $V$. alginolyticus e V. parahaemolyticys e produzir microcápsulas através do processo de secagem por aspersão (spray dryer). Os compostos químicos do óleo essencial de tomilho e das microcápsulas foram identificados e quantificadaos. Foi preparada uma emulsão de óleo em água $(\mathrm{O} / \mathrm{A})$ e em seguida foram produzidas microcápsulas em um spray dryer utilizando-se óleo essencial de tomilho e maltodextrina como material de parede na proporção de 1:4 respectivamente. Entre os vários compostos identificados, o timol apresentou maior concentração. O óleo essencial de tomilho e as microcápsulas exibiram atividade antibacteriana sobre $V$. parahaemolyticus e $V$. alginolyticus. O processo de secagem por aspersão não afetou a atividade antibacteriana do óleo essencial de tomilho.
\end{abstract}

Palavras-chave: óleo essencial, Thymus vulgaris, Thymus zygis, controle bacteriano, aquicultura.

\section{Introduction}

In the Americas are produced about $20 \%$ of total world production of shrimp (Lightner, 2011). White shrimp (Litopenaeus vannamei, Boone) represents $95 \%$ of total production. The countries leading this production are Ecuador, Brazil, Honduras and Mexico (Lightner, 2011). However diseases of viral and bacterial origin, has caused losses in crops, jobs, income and a decrease in exports over the past two decades.

Vibrio spp. mainly located in shrimp digestive tract, gills, cuticle and occasionally in its hemolymph are considered opportunistic pathogens, endemically associated with all stages of life (Lightner, 1993, 2011; Morales-Covarrubias, 
2008). V. parahaemolyticus, V. alginolyticys, V. harveyi and Photobacterium daunselae are the mainly responsible of high levels of shrimp mortality in farms (Morales-Covarrubias, 2008). V. parahaemolyticus is linked to a recent illness in penaeid shrimp production known either as early mortality syndrome (EMS) or as acute hepatopancreatic necrosis disease (AHPND). V. parahaemolyticus affects post larvae with 20-30 days after stock and often cause $100 \%$ of mortality (De Schryver et al., 2014). In the state of Santa Catarina (Brazil) four shrimp farms were monitored and constant presence of Aeromonas hydrophila, $V$. algynolyticus, $V$. parahaemolyticus and Pseudomonas luteola was reported (Padilha et al., 2013).

Controlling bacteria in shrimp, even in conditions of absence of symptoms are essential. They can cause mortality in conditions of stress and weaken the shrimp immune system (Padilha et al., 2013). Therefore, aquaculture industry needs to apply new strategies to control Vibrio spp. infections. An effective alternative to antibiotics and other synthetic compounds are plant compounds such as phenols, polyphenols, alkaloids, quinones, and also components present in essential oils such as terpenoids (Navarrete et al., 2010; Citarasu, 2010). Thyme essential oil has been proved to have antimicrobial, antifungal and antiviral activity (Dorman and Deans, 2000; Burt, 2004; Pina-Vaz et al., 2004; Rota et al., 2008, Nazzaro et al., 2013, Hernández-Hernández et al., 2014). The main problem of the essential oil components is that their biological activity can be lost by volatilization or degradation triggered by high temperatures, oxidation and UV light. Microencapsulation is one of the most efficient methods to protect solids, liquids or even gases against the surrounding environment into microscopic particles protected by a wall material (Soliman et al., 2013).

Spray drying quickly removes water by vaporization from oil-in-water $(\mathrm{O} / \mathrm{W})$ emulsions enabling high retention of volatiles (Badee et al., 2012) and protecting the microencapsulated compounds against reaction with the environment (Madene et al., 2006; Gharsallaoui et al., 2007). Microcapsules consist of a core surrounded by a single or a multilayered wall. Microcapsules with essential oil can be added into the shrimp feed as an ingredient or directly onto the pellet. For this purpose, the materials selected to produce the microcapsules need to be food grade and the powder easily adsorbed by the shrimp. Therefore, casein protein was selected as the emulsifying and maltodextrin as the wall material (Ramakrishnan et al., 2013). This mixture has proved to be very effective for the microencapsulation of oil/fats and volatiles (Sheu and Rosenberg, 1998; Ramakrishnan et al., 2013). The objectives of this research were i) to characterize the main components of thyme essential oil ii) to evaluate their antibacterial effect against $V$. alginolyticus and $V$. parhaemolyticus. iii) to use spray drying to microcapsule these components and iv) to study their antimicrobial effect against $V$. alginolyticus and $V$. parhaemolyticus.

\section{Material and Methods}

\subsection{Identification and quantification of chemical compounds of pure and microencapsulated thyme essential oil by gas chromatography (GC-FID) -mass spectrometry (MS)}

Gas chromatography was performed using a 6890N GC-FID system (AGILENT TECHOLOGIES, Santa Clara, California, USA), equipped with DB-5 capillary column $(30 \mathrm{~m} \times 0.32 \mathrm{~mm} ; 0.50 \mathrm{~mm})$ and connected to a flame ionization detector (FID). GC-MS analyses were performed on an AutoSystem XL GC-MS system (AGILENT TECHNOLOGIES) operating in the EI mode at $70 \mathrm{eV}$, equipped with a split/splitless injector $\left(220^{\circ} \mathrm{C}\right)$. The relative amounts of individual components were calculated using their GC peak areas (Boligon et al., 2013).

\subsection{Bacterial strains and growth conditions}

Vibrio parahaemolyticus (ATCC 17802) and Vibrio alginolyticus (ATCC 17749) were obtained from American Type Culture Collection (ATCC, Rockville, USA). Cultures were transferred to brain heart infusion broth (BHI, Merck, Rio de Janeiro, Brazil) supplemented with $2 \% \mathrm{NaCl}$ (Dinâmica, Diadema São Paulo, Brazil) at $37^{\circ} \mathrm{C}$ for $24 \mathrm{~h}$. Then, growing cultures were stroked on BHI agar (BHIA, Merck, Rio de Janeiro, Brazil) supplemented with $2 \% \mathrm{NaCl}$ (Dinâmica). The plates remained at $37^{\circ} \mathrm{C}$ for $24 \mathrm{~h}$. For inoculum preparation, 2-4 bacterial colonies were selected and transferred to a sterile $0.9 \%$ saline solution, followed by homogenization for $15 \mathrm{~s}$. The turbidity of the solution was adjusted to reach 0.5 on Mc Farland scale (equivalent concentration of $1,5 \times 10^{8}$ cells $\mathrm{mL}^{-1}$ )

\subsection{In vitro antibacterial activity evaluation of thyme essential oil and microencapsulated thyme essential oil}

Broth dilution method (CLSI, 2003) was selected to determine antibacterial activity of $V$. parahaemolyticus and $V$. alginolyticus. Stock solutions of $1 \mathrm{mg} \mathrm{mL}^{-1}$ for thyme essential oil were prepared with $2 \%$ dimethyl sulfoxide (DMSO). Moreover, a stock solution of $1 \mathrm{mg} \mathrm{mL}^{-1}$ of microencapsulated thyme essential oil was also prepared dissolving microcapsules in distilled water. To prepare this solution, the degree of oil entrapment in the microcapsules was taken into account. Four dilutions $\left(0.53,0.26,0.13\right.$ and $\left.0.66 \mathrm{mg} \mathrm{mL}^{-1}\right)$ for thyme essential oil and microencapsulated thyme essential oil were serially prepared in $1.9 \mathrm{~mL}$ of BHI broth (Merck, Rio de Janeiro, Brasil). Each test tube was inoculated with $0.1 \mathrm{~mL}$ of $V$. parahaemolyticus or $V$. alginolyticus and incubated at $37^{\circ} \mathrm{C}$ for $24 \mathrm{~h}$. BHI test tubes with and without $2 \%$ DMSO inoculated with $V$. parahaemolyticus or $V$. alginolyticus were used as positive control, as negative control were used BHI test tubes with and without $2 \%$ DMSO and BHI test tubes with and without $\%$ DMSO supplemented with $0.5 \%$ chloramphenicol. Bacterial growth was identified visually by turbidity of the medium in the tubes, compared with the controls and considered as the lowest concentration capable of inhibiting bacterial growth. Negative growth was confirmed by plating $0.1 \mathrm{~mL}$ of positive sample onto 
BHIA plates and incubated them at $37^{\circ} \mathrm{C}$ for $24 \mathrm{~h}$. Minimum bactericidal concentration (MBC) was considered on the plate, which showed no bacterial growth. All tests were performed by triplicate

\subsection{Preparation and emulsion characterization}

$\mathrm{O} / \mathrm{W}$ emulsions were prepared by mechanical stirring. The emulsifier, $4.17 \mathrm{~g}$ of casein sodium salt (CAS: 9005-46-3, SIGMA-ALDRICH, Saint Louis, MO, USA), was dissolved in $100.14 \mathrm{~g}$ of water and stirred at $300 \mathrm{rpm}$ for $2 \mathrm{~h}$. Then, $20.9 \mathrm{~g}$ of thyme essential oil (white, Food Chemicals Codex, CAS: 8007-46-3, SIGMA-ALDRICH) was added to the solution (water + casein) and homogenized at ambient temperature with an Ultra-Turrax ${ }^{\circledR}$ (model T18, IKA, Staufern, Germany) at 15.000 and $20.000 \mathrm{rpm}$ for $15,30,45$ and 60 min to study the influence of homogenizer speed on the emulsion droplet-size distribution (Figure 1). The droplet-size distributions of the $\mathrm{O} / \mathrm{W}$ emulsions were obtained by laser diffraction measurements using a Malver Mastersizer 2000 equipped with a Hydro 2000 SM dispersion unit (Malvern Instruments Ltd., Worcestershire, England).

\subsection{Spray drying}

$\mathrm{O} / \mathrm{W}$ emulsion was mixed with maltodextrin (dextrose equivalent 16.5-19.5 CAS number 9050-36-6, SIGMAALDRICH, Saint Louis, MO, USA), ratio 1:4 and stirring at $300 \mathrm{rpm}$ for $2 \mathrm{~h}$. To obtain the microcapsules, the $\mathrm{O} / \mathrm{W}$ emulsions were spray-dried using a laboratory scale dryer (Mini Spray Dryer - B290, BÜCHI, Flawil, Switzerland). The emulsion was fed into the spray-dryer at room temperature with a flow rate of $7.5 \mathrm{~mL} \mathrm{~min}^{-1}$. The inlet and outlet temperatures were maintained at $110^{\circ} \mathrm{C}$ and $70^{\circ} \mathrm{C}$, respectively. The dried powder was collected and stored in opaque, airtight container at $4{ }^{\circ} \mathrm{C}$ for further analysis.

\subsection{Powder particle size and microcapsule surface analysis}

The particle size distribution $\left(\mathrm{d}_{3,2}\right)$ of the spray-dried powders was determined using a Malvern Mastersizer 2000 (Malvern Instruments Ltd., Worcestershire, England) equipped with a Scirocco 2000 sample dispersion unit. Each sample was analyzed in triplicate and the data were reported as averages. The outer morphology of the microcapsules was characterized by electronic microscopy. An environmental scanning electron microscope (ESEM, FEI, Quanta 600) was used to analyze the surface morphology of the dried powders. Digital images were taken at an accelerating voltage of $20 \mathrm{kV}$.

\subsection{Total and surface oil determination}

Total oil content of the microcapsules was determined by distilling $5 \mathrm{~g}$ of powder, dissolved in $150 \mathrm{~mL}$ distilled water for $3 \mathrm{~h}$ in a Clevenger-type apparatus. Two $\mathrm{mL}$ of ethyl ether (VETEC, São Paulo, Brasil) were added to extract the essential oil from the water phase. The solution was slowly brought to a boil and allowed to distill. The resulting oil was collected in a pre-weighed Erlenmeyer and the ethyl ether was allowed to evaporate at room temperatures for $24 \mathrm{~h}$ (Fernandes et al., 2014a). The oil encapsulation retention (\%) was calculated using Equation 1:

$$
\text { Oil retention }(\%)=\frac{\text { Total oil in the powder }}{\text { Initial oil load }(\text { dry basis })}
$$

To determine the surface oil a modified method described by Varavinit et al. (2001) was selected. Twenty $\mathrm{mL}$ of hexane were added to $2 \mathrm{~g}$ of powder and the mixture was stirred at $300 \mathrm{rpm}$ for $10 \mathrm{~min}$. The suspension was filtered through a dried cellulose filter and was washed with $20 \mathrm{~mL}$ of hexane three times. The filter was kept in a desiccator under vacuum conditions to vaporize all residual solvent until obtaining constant weight. Finally, the oil encapsulation efficiency (OEE) was calculated using Equation 2 (Ramakrishnan et al., 2013):

$$
\text { OEE }=\frac{\text { Total } \text { oil }- \text { Surface } \text { oil }}{\text { Total } \text { oil }} \times 100
$$

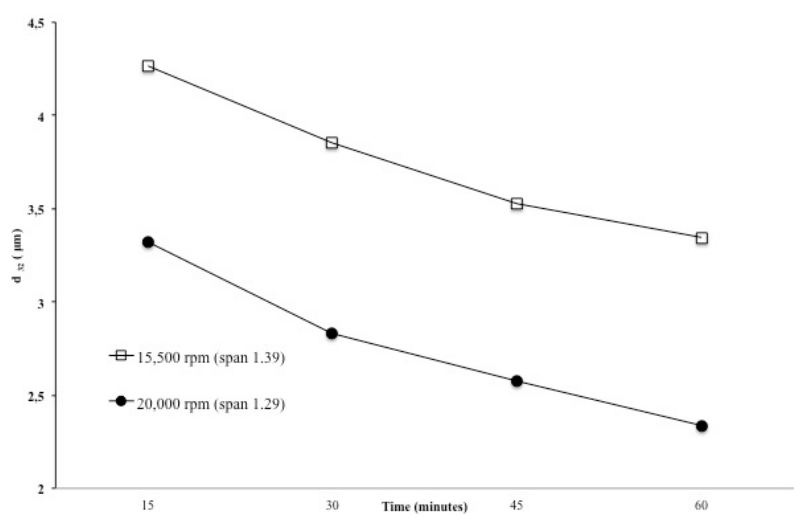

Figure 1. Oil droplet size as $\mathrm{d}_{3,2}$ evolution with the time of speed for the production of thyme essential oil O/W emulsion. 


\subsection{Statistical analysis}

Data analyses were performed using R (R Core Team, 2014) and the add-on package'nls'. Three replicate experiments were run, with duplicate analysis in each of them.

\section{Results and Discussion}

\subsection{Identification and quantification of chemical compounds of thyme essential oil by GC-FID}

Twenty-one compounds were identified in thyme essential oil representing $99.65 \%$ of the total oil composition (Table 1). The main compounds in thyme essential oil were thymol (60.45\%), p-cymene (19.58\%), $\gamma$-terpinene $(4.12 \%)$ carvacrol (3.08\%) and $\beta$-caryophyllene (2.4\%) (Table 1). Thymol and carvacrol are phenolic monoterpenes with antimicrobial activity and the ability to affect the outer membrane of Gram-negative bacteria such as V. parahaemolyticus and V. alginolyticus strains (Helander et al., 1998; Burt, 2004; Nazzaro et al., 2013).

\subsection{In vitro antimicrobial assays of thyme essential oil}

Thyme essential oil exhibited antimicrobial activity against $V$. parahaemolyticus and $V$. alginolyticus. The MBC value for thyme essential oil was 0.125 and $0.25 \mathrm{mg} \mathrm{mL}^{-1}$ for $V$. parahaemolyticus and $V$. alginolyticus, respectively. There are few studies evaluating the action of thyme essential oil against Vibrio spp. in aquatic organisms farming.
Among them Navarrete et al. (2010) and Heo et al. (2012) showed antibacterial activity of this essential oil against fish pathogenic bacteria such as V. parahaemolyticus.

\subsection{Emulsion droplet size}

The equation that describes the size of the particles in the emulsion as a function of time and the stirring speed is, $y=N^{*} e^{-k e^{* t}}$, where y is the droplet size $\left(\mathrm{d}_{3,2}\right), \mathrm{N}$ is the intersection with the $\mathrm{y}$ axis, $\mathrm{k}_{\mathrm{e}}$ is the rate of decrease of particle size, and $t$ is the stirring time (Figure 1). There was not interposition between the confidence interval for $\mathrm{N}$ and $\mathrm{k}_{\mathrm{e}}$ for both treatments, indicating differences between them (Table 2). The decay rate, $\mathrm{k}_{\mathrm{e}}$ was higher for treatment $\mathrm{T}_{2}$ with stirring speed of 20,000 rpm. Reducing emulsion size results in encapsulated powders with higher retention of volatiles and lower content of non-encapsulated oil at the surface of the powder particles (Ramakrishnan et al., 2013). According to these results, the speed of $20.000 \mathrm{rpm}$ was selected to produce the smaller droplet emulsion size under the experimental conditions.

\subsection{Powder particle size}

The mean particle size of the dried power produced was $10.37 \pm 0.0184 \mu$, and the spread of particles, calculated as span, was 1.679 showing homogeneity between the particles. Diameter of the microcapsules produced depended on the material properties, the concentration, the viscosity of the

Table 1. Composition of thyme essential oil and microcapsules obtained by spray drying.

\begin{tabular}{|c|c|c|c|c|c|}
\hline \multirow{2}{*}{ Compound } & \multirow{2}{*}{$\mathbf{R} \mathbf{I}^{\mathbf{a}}$} & \multicolumn{2}{|c|}{ Thyme essential oil } & \multicolumn{2}{|c|}{ Microcapsules } \\
\hline & & $\mathbf{R I}^{\mathbf{b}}$ & Oil \% & $\mathbf{R I}^{\mathbf{b}}$ & Oil \% \\
\hline$\alpha$-thujene & 931 & 933 & 1.05 & 931 & 0.87 \\
\hline$\alpha$-pinene & 939 & 938 & 0.68 & 937 & 0.73 \\
\hline$\alpha$-camphene & 953 & 953 & 0.93 & 950 & 0.81 \\
\hline$\beta$-pinene & 980 & 981 & 0.59 & 983 & 0.37 \\
\hline$\beta$-myrcene & 991 & 989 & 1.04 & 992 & 1.83 \\
\hline$\alpha$-terpinene & 1019 & 1019 & 1.63 & 1019 & 0.79 \\
\hline p-cymene & 1029 & 1027 & 19.58 & 1026 & 15.23 \\
\hline 1.8 cineole & 1033 & 1042 & 1.03 & 1035 & 1.46 \\
\hline$\gamma$-terpinene & 1061 & 1060 & 4.12 & 1059 & 1.73 \\
\hline linalool & 1098 & 1097 & 1.87 & 1098 & 1.95 \\
\hline camphor & 1143 & 1143 & 0.03 & 1140 & 0.01 \\
\hline borneol & 1166 & 1165 & 0.25 & 1161 & 0.47 \\
\hline terpin-4-ol & 1177 & 1179 & 0.09 & 1176 & 0.28 \\
\hline$\alpha$-terpineol & 1189 & 1189 & 0.16 & 1185 & 0.09 \\
\hline thymol & 1290 & 1293 & 60.45 & 1289 & 59.74 \\
\hline carvacrol & 1298 & 1300 & 3.08 & 1298 & 8.12 \\
\hline thymol acetate & 1355 & 1354 & 0.11 & - & - \\
\hline$\beta$-caryophyllene & 1418 & 1419 & 2.4 & 1423 & 1.54 \\
\hline$\alpha$-humelene & 1454 & 1453 & 0.31 & - & - \\
\hline germacreno D & 1480 & 1481 & 0.18 & 1483 & 0.13 \\
\hline$\alpha$-cadidene & 1538 & 1538 & 0.07 & - & - \\
\hline Total identified (\%) & & & 99.65 & & 96.15 \\
\hline
\end{tabular}

Relative proportions of the essential oil constituents were expressed as percentages. ${ }^{2}$ Retention indices from literature (Adams 1995); ${ }^{b}$ Retention indices experimental (base on homologous series $n$-alkane $\mathrm{C}_{7}-\mathrm{C}_{30}$ ). 
encapsulating material, and the operating conditions of the spray dryer (Jafari et al., 2008; Fernandes et al., 2014b). Their value range from 10 to $50 \mu \mathrm{m}$ (Gharsallaoui et al., 2007). The particles exhibited spherical shape (Figure 2), which is typical of materials produced by spray drying (Fernandes et al., 2014b).

\subsection{Total oil, surface oil and oil encapsulation efficiency (OEE)}

Contents of surface oil and total oil in the powders enabled determining the degree of oil entrapment in the capsules. Powders obtained in the study were characterized by microencapsulation efficiency at a level from $87.16 \%$ (Table 3).

The microencapsulation essential oil efficiency (OEE) based on the values obtained for the total surface oil is one of the quality parameters used to determine the amount of oil successfully encapsulated by spray drying (Ramakrishnan et al., 2013).

Oil retention is defined as the ratio of total oil in the final powder to that of the initial oil in the emulsion on dry basis, and it was $57.37 \%$. A similar result was found by Fernandes et al. (2014a) in rosemary essential oil microencapsulation by spray drying that evaluated the effects of gum arabic, modified starch and inulin in various properties of the powder.

\subsection{Identification and quantification of chemical compounds of thyme oil microcapsules by Gas chromatography - mass spectrometry (GC-FID)}

Eighteen compounds were detected in thyme oil microcapsules representing $96.15 \%$ of the total oil composition. The main compounds in thyme oil microcapsules were thymol (59.74\%), p-cymene (15.23\%), carvacrol (8.12\%), linalool $(1.95 \%)$ and $\beta$-myrcene $(1.83 \%)$ (Table 1$)$. The total oil content in thyme oil microcapsules after applying the spray drying process was $11.04 \%$ (Table 3 ). Thymol was the major constituent in thyme essential oil and in the microcapsules. The thymol concentrations in thyme essential oil and in the microcapsules were 60.45 and $59.74 \%$ respectively (Table 1). The microencapsulation by spray drying had a positive effect on the concentration of carvacrol, another phenolic monoterpene with significant antimicrobial activity, (Dorman and Deans, 2000; Rosato et al., 2007) increasing its concentration in 2.63 times approximately (Table 1). Compounds from the alcohols group, 1,8 cineole, linalool, borneol and terpin-4-ol, increased their relative concentrations after microencapsulation. The greatest increases were to terpin-4-ol and borneol with 3.11 and 1.88 times respectively. According to Baranauskiené et al. (2006) phenolic compounds and monoterpenes alcohols contain a hydroxyl group, which can form hydrogen bonds with relevant sites in the protein molecules, enhancing the retention of volatiles after spray drying. In addition, volatiles compounds without hydroxyl group reduced their relative concentration. This phenomenon may be explained by the relatively high temperatures used during the spray drying process. P-cymene and $\alpha$-terpinene showed the highest reduction observed was to with 1.28 and 2.0 times respectively.

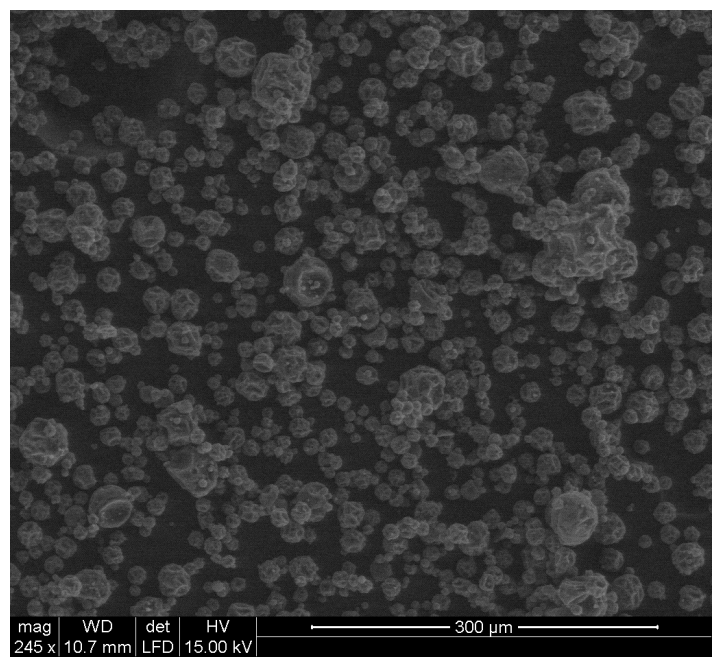

Figure 2. Environmental scanning electron microscope micrograh of thyme oil microcapsules produced with wall material maltodextrin:thyme essential oil load rate of $4: 1$ at magnification of $245 \times$.

Table 2. Estimated $\mathrm{N}$ (intersection with the $\mathrm{y}$ axis) and $\mathrm{k}_{\mathrm{e}}$ (rate of decrease of particle size) parameters obtained using the equation $\mathrm{y}=\mathrm{N} e^{-\mathrm{ke} * \mathrm{~T}}$.

\begin{tabular}{ccc}
\hline Rotor stator & $\mathbf{N}$ & $\mathbf{k}_{\mathbf{e}}$ \\
\hline $15.000 \mathrm{rpm}(\operatorname{span} 1.39)$ & $4.60 \pm 0.11^{\mathrm{a}}$ & $0.0056 \pm 0.0007$ \\
$20.000 \mathrm{rpm}(\operatorname{span} 1.29)$ & $3.68 \pm 0.10$ & $0.0079 \pm 0.0008$ \\
\hline
\end{tabular}

a Standard Deviation (95\%).

Table 3. Encapsulation performance of thyme essential oil.

\begin{tabular}{|c|c|c|c|c|}
\hline $\begin{array}{c}\text { Oil content in the } \\
\text { emulsion } \\
\text { (g oil } 100 \mathrm{~g}^{-1} \text { emulsion) }\end{array}$ & $\begin{array}{c}\text { Total oil } \\
\text { (g oil } 100 \mathrm{~g}^{-1} \text { powder) }\end{array}$ & $\begin{array}{c}\text { Surface oil } \\
\text { (g oil } 100 \mathrm{~g}^{-1} \text { powder) }\end{array}$ & $\begin{array}{l}\text { OEE }^{\mathrm{a}} \\
(\%)\end{array}$ & $\begin{array}{c}\text { Oil retention } \\
(\%)\end{array}$ \\
\hline 19.25 & $11.05 \pm 3.44^{b}$ & $1.42 \pm 0.93^{b}$ & $87.16 \pm 0.67^{b}$ & $57.37 \pm 1.20^{b}$ \\
\hline
\end{tabular}

${ }^{\mathrm{a} O}$ Oil encapsulation efficiency; ${ }^{\mathrm{b}}$ Standard Deviation (95\%). 


\subsection{In vitro antimicrobial assays of thyme essential oil microencapsulated}

Thyme essential oil microcapsules exhibited antimicrobial activity against $V$. parahaemolyticus and V. alginolyticus. The MBC value was 0.25 and $0.25 \mathrm{mg} \mathrm{mL}^{-1}$ for $V$. parahaemolyticus and $V$. alginolyticus, respectively. Therefore, the spray drying process did not have any negative effect on the antimicrobial activity of thyme essential oil and could be used to deliver this compound into shrimp feed without using emulsifiers than can be toxic. In fact, it has been reported that shrimps challenged with $V$. vulnificus, V. parahaemolyticus and $V$. cholerae, and subsequently fed directly with oregano essential oil had significantly reduced the numbers of these bacteria in their tissues (Gracia-Valenzuela et al., 2014).

\section{Conclusions}

The emulsion produced, the wall material used and the spray drying conditions were effective in keeping the major chemical compounds in the thyme essential oil microcapsulated and kept the antimicrobial action against $V$. parahaemolyticus and $V$. alginolyticys. Therefore, the production of thyme oil microcapsules by spray drying may be a promising technique to keep the chemical stability and antimicrobial activity of this essential oil and may be used in aquaculture to fight against the disease associated to $V$. parahaemolyticus and $V$. alginolyticys.

\section{Acknowledgements}

The authors would like to acknowledge FINEP - Recarcina, Ministerio Economía y Competitividad" project CTQ2014-54520-P and Departament d'Enginyeria Química from Universitat Rovira i Virgili from their financial support. In memoriam of Margareth Linde Athayde.

\section{References}

ADAMS, R.P., 1995. Identification of essential oil components by Gas Chromatography/Mass spectroscopy. Illinois: Allured Publishing Corporation. $456 \mathrm{p}$.

BADEE, A.Z.M., AMAL, E.A.E.K. and HANAN, M.A., 2012. Microencapsulation of peppermint oil by spray drying. Australian Journal of Basic and Applied Sciences, vol. 6, no. 12, pp. 499-504.

BARANAUSKIENÉ, R., VENSKUTONIS, P.R., DEWETTINCK, K. and VERHÉ, R., 2006. Properties of oregano (Origanum vulgare L.), citronella (Cymbopogon nardus G.) and majoran (Majorana hortensis L.) flavors encapsulated into milk protein-based marices. Food Research International, vol. 39, no. 4, pp. 413-425. http:// dx.doi.org/10.1016/j.foodres.2005.09.005.

BOLIGON, A.A., FELTRIN, A.C. and ATHAYDE, M.L., 2013. Antioxidant and antimicrobial properties of Guzuma ulmifolia essential oil. American Journal of Essential Oils and Natural Products, vol. 1, pp. 23-27.

BURT, S., 2004. Essential oils: their antibacterial properties and potential applications in foods: a review. International Journal of
Food Microbiology, vol. 94, no. 3, pp. 223-253. PMid:15246235. http://dx.doi.org/10.1016/j.ijfoodmicro.2004.03.022.

CITARASU, T., 2010. Herbal biomedicines: a new opportunity for aquaculture industry. Aquaculture International, vol. 18, no. 3, pp. 403-414. http://dx.doi.org/10.1007/s10499-009-9253-7.

CLINICALAND LABORATORY STANDARDS INSTITUTE CLSI, 2003. Methods for dilution antimicrobial susceptibility tests for bacteria that grow aerobically. 6th ed. Pennsylvania: NCCLS.

DE SCHRYVER, P., DEFOIRDT, T. and SORGELOOS, P., 2014. Early Mortality Syndrome Outbreaks: a microbial management issue in shrimp farming? PLoS Pathogens, vol. 10, no. 4, p. e1003919. PMid:24763380. http://dx.doi.org/10.1371/journal. ppat.1003919.

DORMAN, H.J. and DEANS, S.G., 2000. Antimicrobial agents from plants: antibacterial activity of plant volatile oils. Journal of Applied Microbiology, vol. 88, no. 2, pp. 308-316. PMid:10736000. http://dx.doi.org/10.1046/j.1365-2672.2000.00969.x.

FERNANDES, R.V.B., BORGES, S.V. and BOTREL, D.A., 2014a. Gum arabic / starch / maltodextrin / inulin as wall materials on the microencapsulation of rosemary essential oil. Carbohydrate Polymers, vol. 101, pp. 524-532. PMid:24299808. http://dx.doi. org/10.1016/j.carbpol.2013.09.083.

FERNANDES, R.V.B., MARQUES, G.R., BORGES, S.V. and BOTREL, D.A., 2014b. Effect of solids content and oil load on the microencapsulation process of rosemary essential oil. Industrial Crops and Products, vol. 58, pp. 173-181. http://dx.doi. org/10.1016/j.indcrop.2014.04.025.

GHARSAllaOUi, A., ROUdAUt, G., CHAMBIN, O., VOILLEY, A. and SAUREL, R., 2007. Applications of spraydrying in microencapsulation of food ingredients: an overview. Food Research International, vol. 40, no. 9, pp. 1107-1121. http:// dx.doi.org/10.1016/j.foodres.2007.07.004.

GRACIA-VALENZUELA, M.H., VERGARA-JIMÉNEZ, M.J., BAEZ-FLORES, M.E. and CABRERA-CHAVES, F., 2014. Antimicrobial effect of dietary oregano essential oil against Vibrio bacteria in shrimps. Archives of Biological Sciences, vol. 66, no. 4, pp. 1367-1370. http://dx.doi.org/10.2298/ABS1404367G.

HELANDER, I.M., ALAKOMI, H.L., LATVA-KALA, K., MATTILA-SANDHOLM, T., POL, I., SMID, E.J., GORRIS, L.G.M. and VON WRIGHT, A., 1998. Characterization of the action of selected essential oil components on gram-negative bacteria. Journal of Agricultural and Food Chemistry, vol. 46, no. 9, pp. 3590-3595. http://dx.doi.org/10.1021/jf980154m.

HEO, G.J., KIM, C.H., PARK, S.C., ZOYSA, M. and SHIN, G.W., 2012. Antimicrobial activity of thymol against pathogenic gram-negative bacteria of fishes. Philippine Journal of Veterinary Medicine, vol. 49, no. 2, pp. 103-106.

HERNÁNDEZ-HERNÁNDEZ, E., REGALADO-GONZÀLEZ, C., VÁZQUEZ-LANDAVERDE, P., GUERRERO-LEGARRETA, I. and GARCÍA-ALMENDÁREZ, B.E., 2014. Microencapsulation, chemical characterization and antimicrobial activity of Mexican (Lippia graveolens H. B. K.) and European (Origanum vulgare L.) Oregano essential oils. The Scientific World Journal, vol. 2014, p. 641814. PMid:25177730. http://dx.doi.org/10.1155/2014/641814.

JAFARI, S.M., ASSADPOOR, E., HE, Y. and BHANDARI, B., 2008. Encapsulation efficiency of food flavours and oils during spray drying. Drying Technology, vol. 26, no. 7, pp. 816-835. http://dx.doi.org/10.1080/07373930802135972. 
LIGHTNER, D.V., 1993. Diseases of cultured penaeid shrimp. In: J.P. MCKAY, ed. CRC handbook of mariculture, crustacean aquaculture. Boca Raton: CRC Press, pp. 289-320.

LIGHTNER, D.V., 2011. Virus diseases of farmed shrimp in the Western Hemisphere (the Americas): a review. Journal of Invertebrate Pathology, vol. 106, no. 1, pp. 110-130. PMid:21215359. http:// dx.doi.org/10.1016/j.jip.2010.09.012.

MADENE, A., JACQUOT, M., SCHER, J. and DESOBRY, S., 2006. Flavour encapsulation and controlled release - A review. International Journal of Food Science \& Technology, vol. 41, no. 1, pp. 1-21. http://dx.doi.org/10.1111/j.1365-2621.2005.00980.x.

MORALES-COVARRUBIAS, M.S., 2008. Enfermedades Bacterianas. In: V.Q. MORALES and J. CÚELLAR-ANJEL, eds. Guía técnica: patología e inmunología de camarones penaeidos. Panamá: Programa cyted área de agroalimentación RED II-D: Red Vannamei, pp. 137-152.

NAVARRETE, P., TOLEDO, I., MARDONES, P., OPAZO, R., ESPEJO, R. and ROMERO, J., 2010. Effect of Thymus vulgaris essential oil on intestinal bacterial microbiota of rainbow trout, Oncorhynchus mykiss (Walbaum) and bacterial isolates. Aquaculture Research, vol. 41, no. 10, pp. 667-678.

NAZZARO, F., FRATIANNI, F., MARTINO, L., COPPOLA, R. and FEO, V., 2013. Effect of essential oils on pathogenic bacteria. Pharmaceuticals, vol. 6, no. 12, pp. 1451-1474. PMid:24287491. http://dx.doi.org/10.3390/ph6121451.

PADILHA, P.J.M., VICENTE, L.R.M., COSTA, S.W. and ZAMPARETTE, A.S., 2013. Caracterização das colônias bacterianas isoladas de hemolinfa de camarões Litopenaeus vannamei cultivados no estado de Santa Catarina. In: Resumo: X Simpósio Internacional de Carcinocultura / VII Simpósio Internacional de Aquicultura, 13 June 2013, Natal. Natal: Fenacam pp. 151.

PINA-VAZ, C., RODRIGUES, A.G., PINTO, E., COSTA-DEOLIVEIRA, S., TAVARES, C., SALGUEIRO, L., CAVALEIRO, C., GONÇALVEZ, M.J. and MARTINEZ-DE-OLIVEIRA, J., 2004. Antifungal activity of Thymus oils and their major compounds. Journal of the European Academy of Dermatology and Venereology, vol. 18, no. 1, pp. 73-78. PMid:14678536. http:// dx.doi.org/10.1111/j.1468-3083.2004.00886.x.

R CORE TEAM, 2014. R: A language and environment for statistical computing [software]. Vienna: R Foundation for Statistical Computing.

RAMAKRISHNAN, S., FERRANDO, M., ACEÑA-MUÑOZ, L., LAMO-CASTELLVÍ, S. and GÜELL, C., 2013. Fish oil microcapsules from $\mathrm{O} / \mathrm{W}$ emulsions produced by Premix Membrane Emulsification. Food and Bioprocess Technology, vol. 6, no. 11, pp. 3088-3101. http://dx.doi.org/10.1007/s11947-012-0950-2.

ROSATO, A., VITALI, C., LAURENTIS, N., ARMENISE, D. and MILILLO, M.A., 2007. Antibacterial effect of some essential oils administered alone or in combination with Norfloxacin. Phytomedicine, vol. 14, no. 11, pp. 727-732. PMid:17303397. http://dx.doi.org/10.1016/j.phymed.2007.01.005.

ROTA, M.C., HERRERA, A., MARTÍNEZ, R.M., SOTOMAYOR, J.A. and JORDÁN, M.J., 2008. Antimicrobial activity and chemical composition of Thymus vulgaris, Thymus zygis and Thymus hyemalis essential oils. Food Control, vol. 19, no. 7, pp. 681-687. http://dx.doi.org/10.1016/j.foodcont.2007.07.007.

SHEU, T.Y. and ROSENBERG, M., 1998. Microstructure of microcapsules consisting of whey proteins and carbohydrates. Journal of Food Science, vol. 63, no. 3, pp. 491-494. http://dx.doi. org/10.1111/j.1365-2621.1998.tb15770.x.

SOLIMAN, E.A., EL-MOGHAZY, A.Y., EL-DIN, M.S.M. and MASSOUD, M.A., 2013. Microencapsulation of essential oils within alginate: formulation and in vitro evaluation of antifungal activity. Journal of Encapsulation and Adsorption Sciences, vol. 3, no. 1, pp. 48-55. http://dx.doi.org/10.4236/jeas.2013.31006.

VARAVINIT, S., CHAOKASEM, N. and SHOBSNGOB, S., 2001. Studies of flavor encapsulation by agents produced from modified sago and tapioca starches. Starch, vol. 53, no. 6, pp. 281-287. http://dx.doi.org/10.1002/1521-379X(200106)53:6<281::AIDSTAR281>3.0.CO;2-R. 